\title{
BOSTONIA PERPLEXA GEN. ET SP. NOV., A CALAMOPITYAN AXIS FROM THE NEW ALBANY SHALE OF KENTUCKY ${ }^{1}$
}

\author{
William E. Stein, Jr. and Charles B. Beck \\ Department of Botany. University of Michigan, Ann Arbor 48109
}

\author{
A B S T R A C T
}

\begin{abstract}
Bostonia perplexa, gen. et sp. nov., was collected from the Lower Mississippian Falling Run member of the Sanderson Formation. The single short segment of an axis, preserved as a petrifaction, contains at least three vascular columns, each with both primary and secondary tissues. Primary xylem is two or three ribbed, and contains several mesarch protoxylem strands. Gymnospermous secondary xylem is characterized by both uniseriate and multiseriate rays. The ground tissue is parenchymatous except for a few clusters of sclerotic cells. In its apparent polystelic nature, the specimen superficially resembles members of the Pennsylvanian to Permian Medullosaceae. All evidence currently available. however, leads to the conclusion that this species should be placed in the Upper Devonian to Lower Mississippian Calamopityaceae. It has not been determined with certainty whether the species is polystelic (in the sense of the Medullosaceae), or whether the apparent polystely is the result of stelar branching proximal to the level of branch divergence.
\end{abstract}

A SPECIMEN collected from the Falling Run member of the Sanderson Formation and described in this paper represents a new member of the New Albany Shale flora. The vascular plant flora of the New Albany Shale is quite diverse, containing members from the Progymnospermopsida, Lycopsida, Pteridospermales, Cladoxylales, and Coenopteridales. Several plants are not clearly assignable to any one group, but show characters usually associated with two or more of these groups.

The age of the Sanderson Formation has been the subject of some controversy since it appears to straddle the Upper Devonian-Lower Mississippian boundary: Campbell (1946) concludes that the Sanderson Formation is lower-most Mississippian and the remainder of the New Albany Shale Upper Devonian in age. Hass $(1947,1956)$ places all but the nodular, Falling Run member of the Sanderson in the Upper Devonian, but agrees that this plant-bearing stratum is Lower Mississippian.

The first major paper indicating the diversity of the New Albany Shale flora was that of Scott and Jeffrey (1914). Additions of new taxa have been made by Read (1936a, 1936b, 1937), Read and Campbell (1939), Beck (1960, 1962), Hoskins and Cross (1951a), Beck and Bailey (1967),

\footnotetext{
${ }^{1}$ Received for publication 12 September 1977; revision accepted 29 November 1977.

Supported by NSF grants GB8100X and BMS 75-14861 to C. B. Beck.

The final rendering of Fig. 7 is the work of Derwin Bell, that of Fig. 8, the work of Constance Stein.

The authors thank Dr. Robert Lowry for his assistance in the photography of parts of the specimen.
}

among others. Reviews of the flora and stratigraphy of the Devonian black shales were contributed by Hoskins and Cross (1951b) and Cross and Hoskins (1951).

As might be expected from its position in the geologic column, the New Albany Shale flora contains some elements typical of both the Upper Devonian and Lower Mississippian floras. With the exception of Callixylon, however, the flora of the Falling Run member of the Sanderson has a predominantly Lower Mississippian aspect, containing, with others, members of the Calamopityaceae and Coenopteridales. In North America, the flora is distinctive in composition, but it is nearly identical with the Lower Carboniferous flora of the Lydiennes Formation of France (see Galtier, 1970). Also, it contains much in common with the Calciferous sandstone flora of Lower Carboniferous age in Great Britain (Gordon, 1938; Long, 1961, 1963, 1964).

Although the New Albany Shale flora usually is considered to be restricted to the region of the former Cincinnati Dome, recent evidence suggests that some taxa of the flora have a more widespread distribution. Until recently Stenokoleos was known only through two species in this flora (Hoskins and Cross, 1951a; Beck, 1960), but a third species has been discovered in the Oneonta Formation (lower Upper Devonian) of Schoharie County, New York (Matten and Banks, 1969). Similarly, Siderella, known previously only from the New Albany Shale (Read, 1936a) has been collected recently by J. D. Grierson (personal communication) from the Lower Mississippian Pocono Formation of Pennsylvania. The discovery, in continental sediments of 
the eastern United States, of structurally preserved axes of taxa represented in the New Albany Shale flora leads to optimism that ultimately the nature of these plants may be clarified due to the possibility of associating them with compressions providing information on external morphology.

The specimen described in this paper is an example of an unusually difficult problem of interpretation that might easily be clarified in a more complete specimen. Its apparent polystelic structure combined with typically pteridospermic features of primary and secondary xylem, and trace architecture, might indicate a relationship with members of the Medullosaceae which are much younger in age. (Polystelic plants of nearly the same age such as Xenocladia, Voelkelia, and Cladoxylon have also been considered, but they are clearly fundamentally different in structure.) On the other hand, a careful study of pteridosperm-like plants of nearly the same age as our specimen is particularly important since the stelar pattern in a region of branching can give a localized and false appearance of polystely.

DESCRIPTION-The specimen is about $2 \mathrm{~cm}$ long, more or less cylindrical in shape with a diameter of 1.5 to $2.1 \mathrm{~cm}$, having been compressed only slightly during preservation. As seen in cross section, the specimen consists of a ground mass of thin-walled parenchyma cells in which are located three columns of vascular tissue. In addition, a small fragment of secondary xylem at the periphery of the specimen may indicate the position of a fourth vascular column, or a departing trace (Fig. 1). Surrounding the vascular columns in regions of presumed phloem, extensive masses of sclereids are observed. There are also clusters of sclerotic cells occurring between vascular columns and peripherally. Except for these sclerotic bodies, preserved ground tissue is homogeneous with no indication of layering as might be seen in Heterangium. However, epidermis is not present and the specimen is most certainly incomplete.

The ground tissue-Sclerotic bodies (Fig. 8) are spheroidal and are comprised of thick-walled cells usually isodiametric toward the centers of the bodies and becoming increasingly elongated toward the peripheries. These cells, which contain dark lumina, vary in diameter from $40 \mu \mathrm{m}$ to $53 \mu \mathrm{m}$ in the center of the bodies. to $67 \mu \mathrm{m}$ by $100 \mu \mathrm{m}$ toward the peripheries. Large, elongate parenchyma cells radiate from some but not all of the sclerotic bodies. These parenchyma cells appear thinner walled than the cells inside the sclerotic bodies, but this actually may be an accident of preservation. The elongate parenchyma cells contain no dark substances in their lumina. They mesh with smaller elongate cells along the rims of the sclerotic bodies toward the inside, and with the general ground parenchyma cells peripherally. These cells have dimensions of $200 \mu \mathrm{m}$ to $216 \mu \mathrm{m}$ by $72 \mu \mathrm{m}$ to $86 \mu \mathrm{m}$, whereas typical cells of the ground tissue vary in average size from $132 \mu \mathrm{m}$ by $81 \mu \mathrm{m}$ toward the periphery of the specimen, to $228 \mu \mathrm{m}$ by $72 \mu \mathrm{m}$ between vascular columns as seen in transverse section.

The direction and degree of elongation of the general ground parenchyma cells, as well as of those surrounding the sclerotic bodies, seem to be influenced by their proximity to vascular columns. Although each elongate parenchyma cell adjacent to a sclerotic body shows elongation along an axis leading directly toward the center of the body, those whose axis of elongation is most nearly perpendicular to the direction of rays of the nearest vascular column are noticeably more elongate (Fig. 8). The long axis of general ground parenchyma cells, seen in transverse section, is also perpendicular to the direction of the nearest vascular ray. This pattern may be related to forces generated in the stem during production of secondary xylem, since elongation of parenchyma cells is more noticeable near the center of the specimen, between vascular columns, and less so toward the outer edge.

Other masses of small cells containing dark substances, probably sclereids, are found just outside the secondary xylem in the regions of phloem (Fig. 4). These cell clusters are comprised of isodiametric cells with an average size of $60 \mu \mathrm{m}$ to $90 \mu \mathrm{m}$ in diam, but are not enclosed by radiating parenchyma. The clusters vary greatly in number of cells they include. No recognizable phloem conducting elements are preserved.

Fig. 1-6. Bostonia perplexa. 1. Holotype, showing arrangement of vascular columns, in transverse section, of the stem fragment. Arrow (a) indicates a fragment of secondary xylem at the periphery of the specimen. Arrow (b) indicates several tangential layers of cells in the ground parenchyma. \#122-2. $\times 5$. 2. Radial section of secondary xylem showing multiseriate bordered pit pairs. \#122-15L. $\times 290$. 3. Higher magnification of the lower-left vascular column in Fig. 1, showing the threeribbed primary xylem and incipient traces. $\times 11$. 4. Increased magnification of a portion of the lower-left vascular column in Fig. 3, showing a greatly expanded ray and a mass of sclereids in a presumed region of phloem (arrow). $\times 55$. 5. Detail of the primary xylem of the lower-left vascular column in Fig. 3. Protoxylem strands indicated by arrows. $\times 50$. 6. Incipient trace of lower-left vascular column showing branched protoxylem strand (arrows). $\times 18$. 
(1)

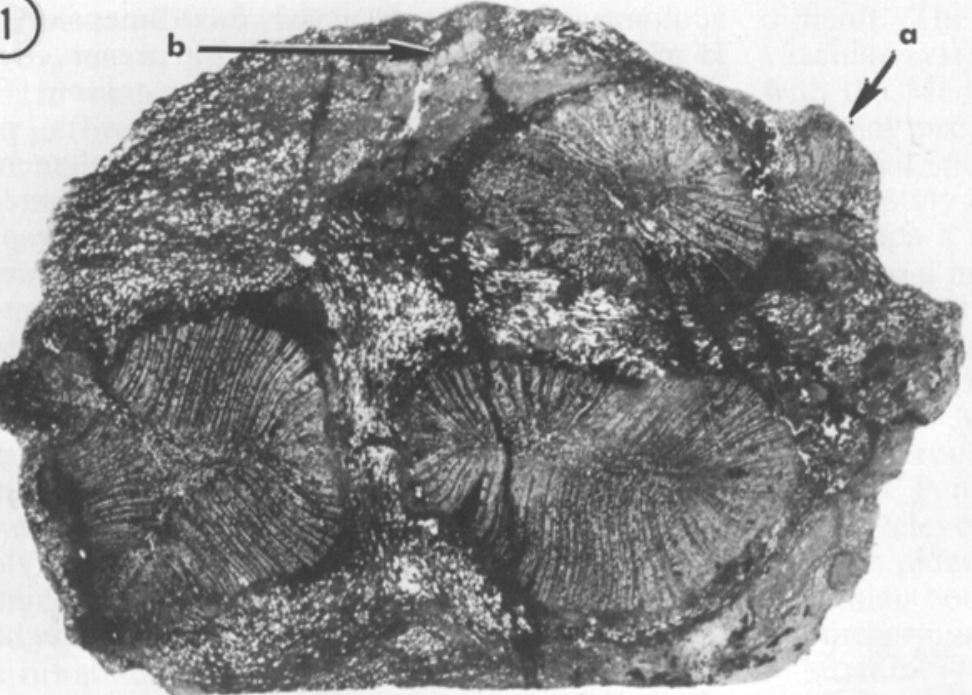

(2) 13 ovis

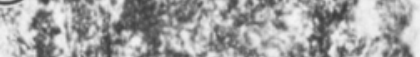

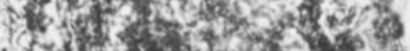

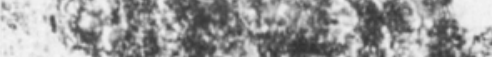

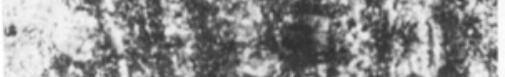

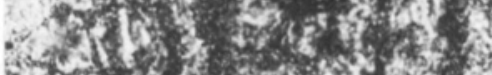

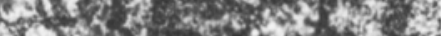

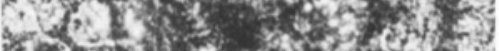

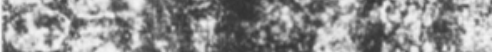

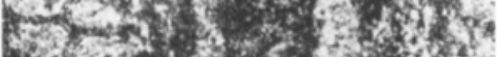

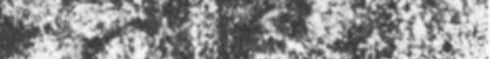

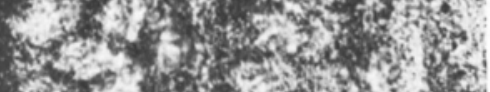
R.

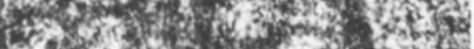
2.

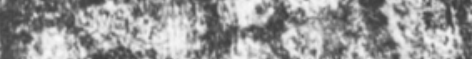
4.

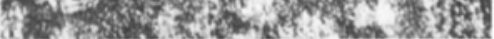

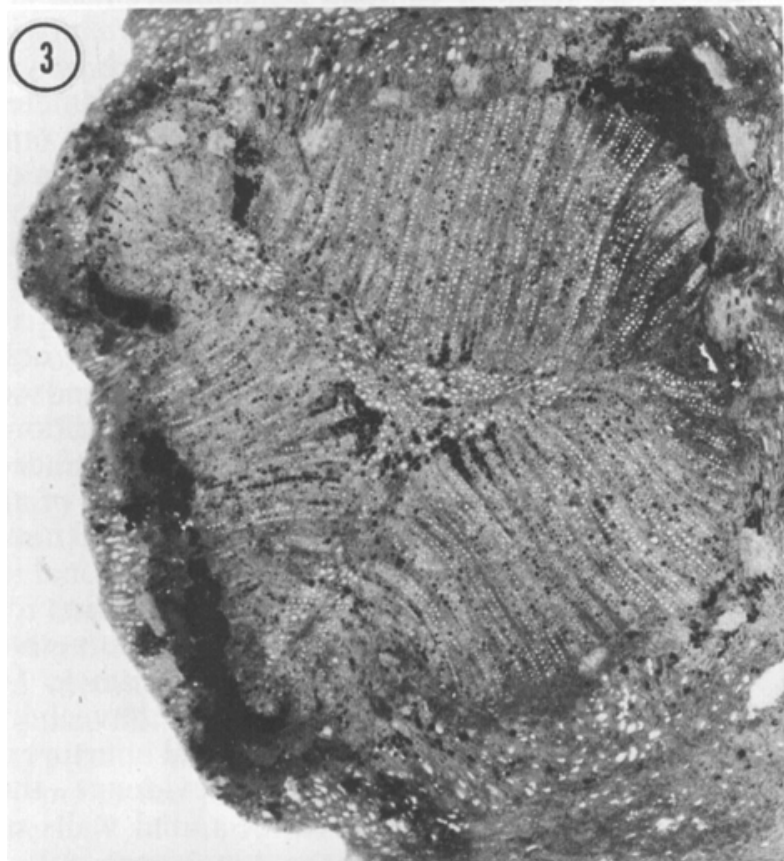

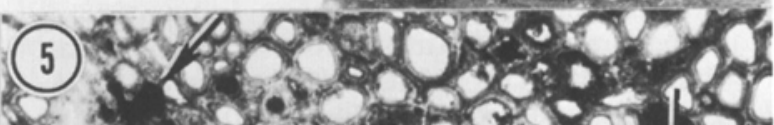

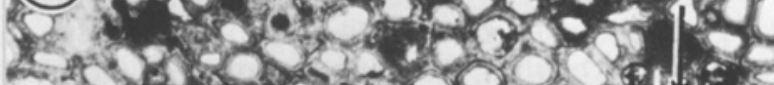

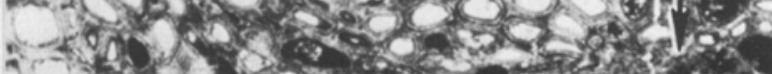

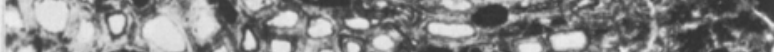

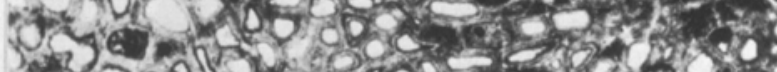

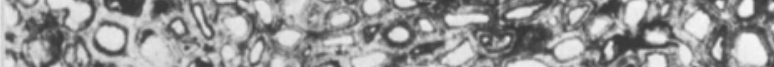
Her of

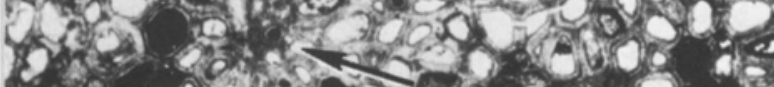

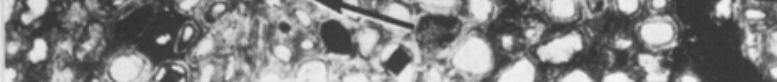

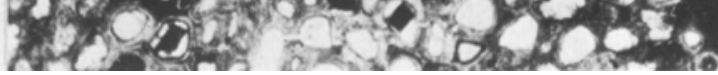
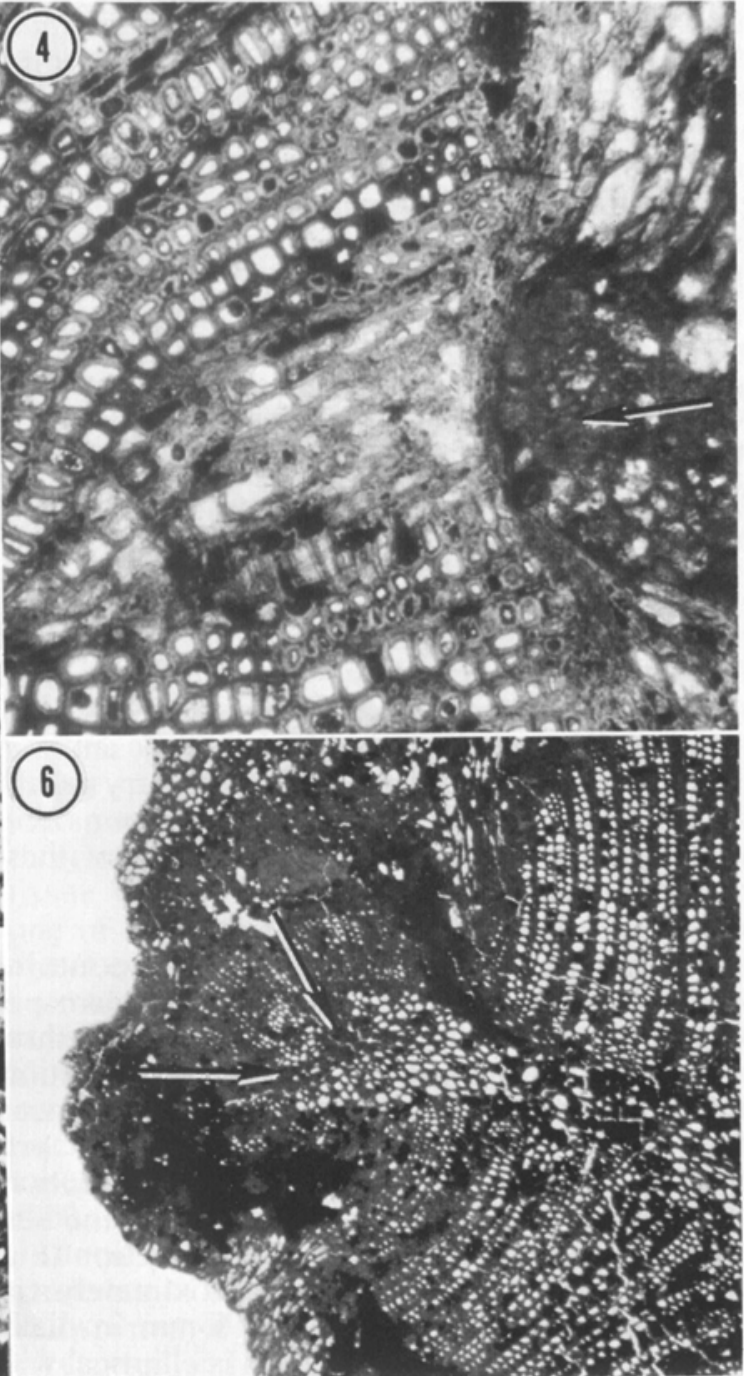
7
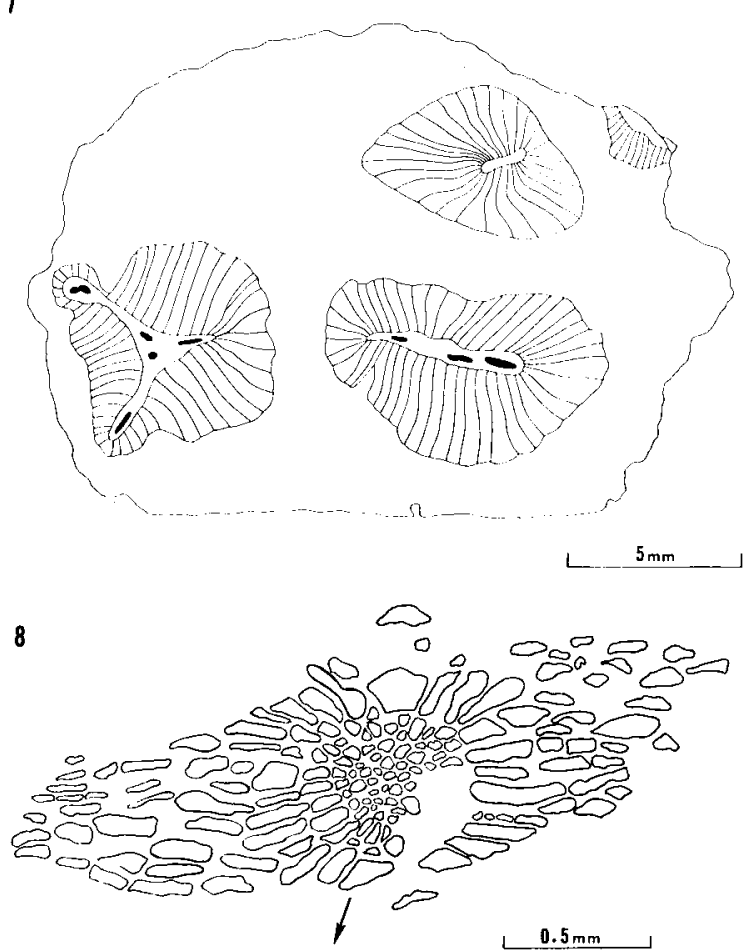

Fig. 7. 8. Bostonia perplexa. 7. Camera lucida diagram showing the configuration of the vascular columns in transverse section. Secondary xylem is represented by radiating lines; solid black represents protoxylem strands; white regions inside secondary xylem indicates metaxylem. 8. Camera lucida drawing of a sclerotic body surrounded by elongate parenchyma of the ground tissue as seen in transverse section. Direction of the center of the nearest vascular column is indicated by the arrow. Only the outlines of cell lumina have been drawn.

Several tangential layers of cells are located near the periphery of the specimen in a small portion of the ground tissue (Fig. 1). These cells are small, somewhat poorly preserved, and may have had thickened walls. Cell sizes vary greatly from $30 \mu \mathrm{m}$ in diam to $40 \mu \mathrm{m}$ by $90 \mu \mathrm{m}$ as seen in transverse section. The significance of these cells is unclear.

Vascular tissues - The specimen contains three vascular columns, each with its own primary and secondary xylem (Fig. 1). The three columns are in various states of preservation. The vascular column represented to the lowerleft in Fig. 1 shows the most completely preserved structure as seen in transverse section. The lower-right vascular column shows the best detail of wall pitting in longitudinal section (Fig. 2 ). The lower-left column is approximately circular in transverse outline and $6 \mathrm{~mm}$ in diam. The lower-right vascular column is elliptical with dimensions of $9 \mathrm{~mm}$ by $5 \mathrm{~mm}$. The upper-right column, not well preserved, has dimensions of $6 \mathrm{~mm}$ by $4 \mathrm{~mm}$. Two traces are preserved diverging from the lower-left vascular column (Fig. 3). A fragment of secondary xylem with, perhaps, some associated primary xylem elements, is preserved at the extreme periphery of one of our sections (Fig. 1). This fragment may represent a trace or an additional vascular column.

Primary xylem-Primary xylem (Fig. 3) seems to consist solely of tracheids, showing no evidence of xylem parenchyma, and comprises twoor three-ribbed columns. Development of primary xylem is mesarch. Protoxylem strands (three in the lower-left vascular column) are located toward the center of the primary xylem column (Fig. 5), and they are also associated with the incipient leaf traces (Fig. 6). Branching of one of the central protoxylem strands (in the lower-left vascular column) is reminiscent of the pattern of trace divergence seen in Tetrastichia (Gordon, 1938). Protoxylem tracheids are polygonal in transverse section and range in diameter from $23 \mu \mathrm{m}$ to $34 \mu \mathrm{m}$. The metaxylem is composed of polygonal tracheids also. The largest of them are located near the centers of primary $x y-$ lem columns or traces. Metaxylem tracheids vary from $39 \mu \mathrm{m}$ to $110 \mu \mathrm{m}$ in diam (Fig. 5).

Secondary xylem-Each primary xylem column is enclosed in secondary xylem composed of tracheids and ray cells (Fig. 4). In addition, secondary xylem is associated with the traces (Fig. 6). Thickness of the secondary xylem of all vascular columns ranges from $1.5 \mathrm{~mm}$ to $3.0 \mathrm{~mm}$. Tracheids are mostly hexagonal or pentagonal in transverse section and may increase in size toward the outside of the column. Cell diameters range, in transverse section, from $34 \mu \mathrm{m}$ to 54 $\mu \mathrm{m}$. The secondary xylem tracheids have bordered pit-pairs with crossed, elliptical apertures, and on the basis of all available evidence, the pits seem to be restricted to the radial walls of the elements.

Rays are either uniseriate or multiseriate, with the latter type predominating. Some rays are greatly dilated toward the periphery of the column, particularly those in the lower-left vascular column facing the lower-right column (Fig. 4). Indeed, rays which are expanded to the greatest extent are invariably located closest to neighboring vascular columns. Ray cells vary greatly in size and shape. Some, as seen in radial section, have a length of $140 \mu \mathrm{m}$ and a height of 90 $\mu \mathrm{m}$. Secondary phloem cannot be characterized. Probably, it was located concentrically around each vascular column since there are cylindrical regions of poorly preserved tissue, containing masses of sclereids, surrounding each of them. 
Traces-Two incipient traces are located, one each, on two of the three primary xylem ribs of the lower-left vascular column in Fig. 1. One of these (Fig. 6) seems slightly more extended than the other and presumably would be the first to diverge distally. This trace is composed of a subtriangular (in transverse configuration) primary xylem column containing one mesarch protoxylem strand eccentrically placed toward the periphery of the stem. The protoxylem clearly appears to be dividing. This fact suggests that distally, traces may divide, perhaps several times, in a way similar to that observed in $\mathrm{Cal}$ amopitys or Stenomyelon. An arch of secondary xylem adjoins the primary xylem to the outside.

The other trace (Fig. 3, Fig. 7) is not quite as large, and shows only one radially elongated protoxylem strand. In other details however, it is very similar to the trace just mentioned. No trace is found associated with the third rib of the lower-left vascular column, although division of the central protoxylem strand associated with this rib clearly indicates the possibility of a more distal divergence of a trace. It is possible, however, that divergence of traces here was suppressed by the presence of the lower-right vascular column. This, combined with the observed great distention of rays located nearest the adjacent lowerright vascular column, may indicate a more proximal connection between these two, now separate, vascular columns.

The nature of "phyllotaxis" for the entire stem is impossible to determine, given the fragmentary nature of the specimen and the small number of traces present.

Discussion-Affinities of the specimen-The plant, represented by this specimen, is probably a member of the order Pteridospermales. Evidence for this assignment may be seen in the typically manoxylic nature of its secondary $x y-$ lem, in the presence of sclerotic bodies characteristic of many plants in this group, in traces with associated secondary vascular elements, and in the presence of multiseriate, bordered pit pairs in the secondary xylem apparently restricted to the radial walls of tracheids. However, definitive assignment of our specimen to the Pteridospermales must await discovery of further evidence including fructifications. The specimen seems not to be related to the polystelic Cladoxylales such as Cladoxylon or Xenocladia (Scott, 1923; Arnold, 1952). Obvious departures from characteristic cladoxylalean structure include the absence of "peripheral loop" protoxylem strands, and the presence of typically gymnospermous secondary xylem.

Assignment of our specimen to any of the existing pteridosperm families becomes much more difficult. The apparent polystelic nature of its vascular system suggests a possible relationship with the Medullosaceae. Although this relationship may prove to be correct upon discovery of additional specimens, at the present time possible polystely is the only characteristic which suggests such a relationship. Certainly a major objection to a medullosan affinity for our specimen arises from the tremendous time gap in the geological record between the earliest known members of the Medullosaceae and that of our specimen. The Medullosaceae occur from Upper Carboniferous through Permian in Europe, and from the Pennsylvanian through Permian in the USA (Delevoryas, 1955), whereas our specimen is much older, occurring near the MississippianDevonian boundary.

Furthermore, the primary xylem of our specimen differs from that seen in the Medullosaceae in three major respects: 1) the primary xylem contains only tracheids, whereas all known Medullosaceae have abundant xylem parenchyma; 2 ) The primary xylem in one of the three vascular columns of the new specimen is radially three ribbed, whereas all Medullosaceae have irregular, but basically tangentially oriented primary xylem segments; 3) The three ribbed vascular column in our specimen contains centrally located protoxylem strands, whereas the protoxylems of the Medullosaceae are all located peripherally with respect to the stelar system of the axis as a whole.

Because our specimen represents only a short segment of axis, we must consider the important fact that branching sometimes gives a localized and false appearance of polystely. A good example of this is seen in Scott's (1923 p. 39) figures of Lyginopteris oldhamia. In this example, branching produced two subequal vascular columns enclosed in a common cortex throughout some length of the axis.

Our specimen likewise might be part of an axis just proximal to branching. It shows at least three vascular columns within a common ground tissue with definite traces associated with only one of the three columns. Although there is no direct evidence of branching in the specimen, the secondary xylem on facing sides of adjacent vascular columns shows greatly expanded rays. Similar dilation of rays has been observed in many other specimens distal to the level of leaf trace or branch stele divergence from the main vascular column (e.g., Beck and Bailey, 1967, p. 1000, Fig. 4).

Because of the uncertainty over the stelar structure of our specimen, comparison with pteridosperms of nearly the same age, the Calamopityaceae and Lyginopteridaceae, poses some difficulties. If the stelar structure of our speci- 
men were found to represent a longitudinally constant condition, then this plant certainly would be unique among pteridosperms of Mississippian age. The only direct evidence tending to support the interpretation of a "polystelic" condition for our specimen is the presence of three, perhaps even four, vascular columns in the same cortex. The presence of more than two vascular columns at one level does not preclude the possibility of this being a segment of axis just proximal to a diverging branch system, but in our opinion it reduces somewhat the probability of it being so.

Comparing any single vascular column of this specimen with vascular architecture of any Lower Mississippian or Upper Devonian member of the Pteridospermales is of questionable value, even if we assume that the vascular columns represent telomic homologues or branching steles. The lower left column is radially three ribbed and appears very similar to Stenomyelon primaevum (Long, 1964) except for the presence of centrally situated protoxylem strands apparently producing traces in a manner similar to that seen in Tetrastichia (Gordon, 1938). However, the lower right vascular column is completely different in structure. Its elongate-elliptical primary xylem configuration, including several protoxylem strands, might suggest completely different relationships.

The anatomical characteristics detailed above suggest that our specimen should be assigned to the Calamopityaceae of the Pteridospermales. Its unusual collection of characters is sufficiently unique to warrant its generic distinction, but more information is needed in order to determine its affinities accurately.

If, in the future, a definite relationship with the Medullosaceae were established for our specimen, then an attempt to reconcile it with the two currently competing hypotheses of medullosan stelar evolution (Stewart, 1976; Basinger, Rothwell, and Stewart, 1974; Delevoryas, 1955) should be made. At this time however. we believe that discussion of medullosan evolution on the basis of this specimen would be unproductive.

Bostonia perplexa, gen. et sp. nov.

Combined diagnosis-A stem segment, $2 \mathrm{~cm}$ long and $1.5-2.1 \mathrm{~cm}$ in diam. Ground tissue containing three vascular columns, scattered sclerotic bodies, and clusters of sclereids in the region of the phloem. Vascular columns variable in transverse size and form: $6 \mathrm{~mm}$ in diam and circular, $9 \times 5 \mathrm{~mm}$ and elliptical, and $6 \times 4 \mathrm{~mm}$ and elliptical. Vascular columns with both primary and secondary xylem. Primary xylem columns two or three ribbed, comprised of a com- pact tissue of tracheids containing no obvious parenchyma. Primary xylem mesarch, internal, associated with the vascular columns and with incipient traces; protoxylem tracheids 23 $\mu \mathrm{m}-34 \mu \mathrm{m}$ in transverse diam; metaxylem tracheids $39 \mu \mathrm{m}-110 \mu \mathrm{m}$ in transverse diam. Secondary xylem manoxylic with rays one to many cells high; tracheids $34 \mu \mathrm{m}-54 \mu \mathrm{m}$ in transverse diam; pitting multiseriate, circular bordered. Traces characterized by associated secondary xylem. The single protoxylem strand of a trace dividing at least once, tangentially, during trace divergence. Sclerotic bodies in ground tissue with a central core of isodiametric, sclerified cells 40 $53 \mu \mathrm{m}$ in diam, intergrading at the periphery of the cluster with elongate parenchyma cells with dimensions of $100 \mu \mathrm{m} \times 67 \mu \mathrm{m}$. Sclereids in the region of phloem isodiametric, $60 \mu \mathrm{m}-90 \mu \mathrm{m}$ in diam. General ground parenchyma showing evidence of compression between vascular columns and consisting of cells with a size range of from $81 \mu \mathrm{m} \times 132 \mu \mathrm{m}$ to $228 \mu \mathrm{m} \times 72 \mu \mathrm{m}$ in transverse section.

Holotype-Twenty five slides bearing number 62028 in the Museum of Paleontology of the University of Michigan, Ann Arbor, Michigan.

Horizon and Locality-Falling Run Member of the Sanderson Formation (Lower Mississippian [Tournasian]), New Albany Shale near Boston, Kentucky.

\section{LITERATURE CITED}

ArNol. D, C. A. 1952. Observations on fossil plants from the Devonian of eastern North America VI. Xenocladia medullosina Arnold. Contrib. Mus. Paleontol. Univ. Mich. 9: 297-309.

Basinger, J. F., G. W. Rothwell, and W. N. Stewart. 1974. Cauline vasculature and leaf trace production in medullosan pteridosperms. Amer. J. Bot. 61: 1002-1015.

BECK, C. B. 1960. Studies of New Albany shale plants. I. Stenokoleos simplex comb. nov. Amer. J. Bot. 47: $115-$ 124.

1962. Plants of the New Albany shale. II. Callixylon arnoldii sp. nov. Brittonia 14: 322-327.

- AND R. E. BAiley. 1967. Plants of the New Albany shale. II. Chapelia campbellii gen. n. Amer. J. Bot. 54: 998-1007.

Campbell. G. 1946. New Albany Shale. Bull. Geol. Soc. Am. 57: 829-908.

Cross, A. T., And J. H. Hoskins. 1951. Paleobotany of the Devonian-Mississippian black shales. J. Paleontol. 25: 713-728.

Delevoryas, T. 1955. The medullosae-structure and relationships. Palaeontogr. Abt. B. Palaeophytol. 97: 114167.

Galtier. J. 1970. Recherches sur les végetaux à structure conservée du Carbonifère inférieur francais. Paleobiologie Continentale 1: 1-221.

Gordon, W. T. 1938. On Tetrastichia bupatides: a Carboniferous pteridosperm from East Lothian. Trans. R. Soc. Edinb. 59: 351-370. 
Hass, W. H. 1947. Conodont zones in Upper Devonian and Lower Mississippian formations of Ohio. J. Paleontol. 21: $131-141$.

1956. Age and correlation of the Chattanooga Shale and the Maury Formation. U.S. Geol. Surv., Prof. Pap. 286: $1-47$.

Hoskins, J. H., AND A. T. Cross, 1951a. The structure and classification of four plants from the New Albany Shale. Amer. Midl. Nat. 46: 684-716.

- AND . 1951b. The petrifaction flora of the Devonian-Mississippian black shale. Paleobotanist 1: 215-238.

Long, A. G. 1961. Tristichia ovensi gen. et sp. nov., a protostelic Lower Carboniferous pteridosperm from Berwickshire and East Lothian, with an account of some associated seeds and cupules. Trans. R. Soc. Edinb. 64: $477-489$.

. 1963. Some specimens of Lyginorachis papilio Kidston associated with stems of Pitys. Trans. R. Soc. Edinb. 65: $211-224$.

. 1964. Some specimens of Stenomyelon and Kalymma from the calciferous sandstone of Berwickshire. Trans. R. Soc. Edinb. 65: 435-447.
Matten, L. C., AND H. P. Banks, 1969. Stenokoleos bifidus sp. $\mathrm{n}$. in the upper Devonian of New York State. Amer. J. Bot. 56: 880-891.

ReAD, C. B. 1936a. A Devonian flora from Kentucky. J. Paleontol. 10: 215-224.

- 1936b. The flora of the New Albany shale. Part 1. Diichnia kentuckiensis, a new representative of the Calamopityeae. U.S.G.S. Prof. Pap. 185-H: 149-155.

1937. The flora of the New Albany shale. Part 2. The Calamopityeae and their relationships. U.S.G.S. Prof. Pap. 186-E: 81-104.

- AND G. CAMPBell. 1939. Preliminary account of the New Albany shale flora. Am. Midl. Nat. 21: 435453.

Scotr, D. H. 1923. Studies in fossil botany, Vol. 2, 3rd Ed. A. and C. Black, London.

AND E. C. JEFFrEY. 1914. On fossil plants, showing structure, from the base of the Waverly shale of Kentucky. Philos. Trans. R. Soc. London B205: 315-373.

Stewart, W. N. 1976. Polystely, primary xylem and the Pteropsida. 21 st Sir A. C. Seward Mem. Lecture. Sahni Inst. Paleobot. 1-13. 